跣七拾式百第睸雑會拲類人京東

\begin{tabular}{|c|c|c|c|c|c|c|c|c|c|c|c|c|c|c|c|c|c|}
\hline 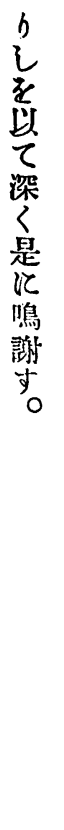 & 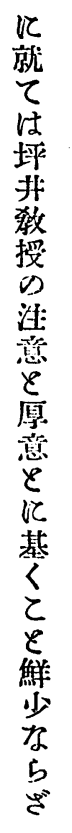 & 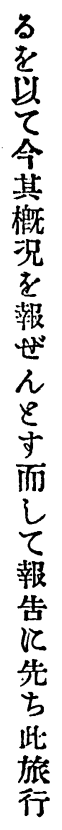 & 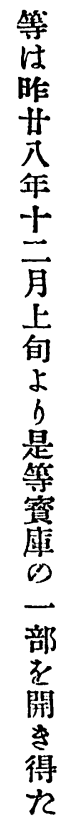 & 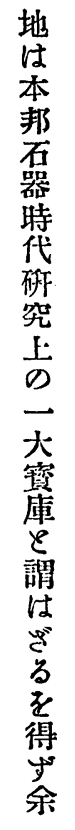 & 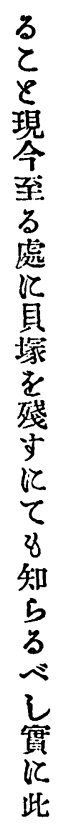 & 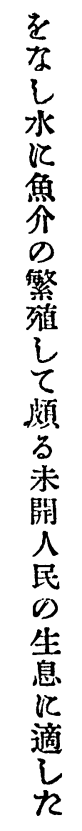 & 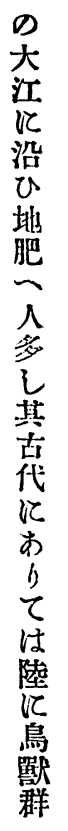 & 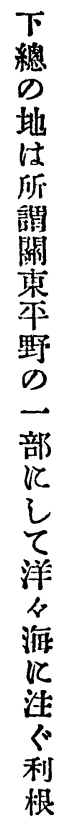 & $\begin{array}{l}\text { 林 } \\
\text { 漼 } \\
\text { 吉 }\end{array}$ & $\begin{array}{l}\text { 八 } \\
\text { 木 } \\
\text { 娤 } \\
\text { 三 } \\
\text { 郎 }\end{array}$ & 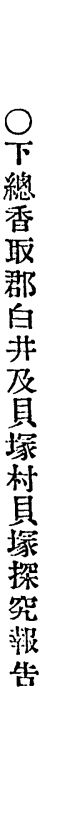 & & 杂 & 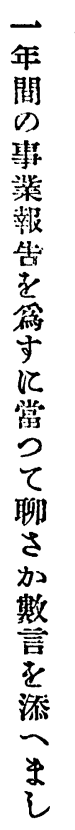 & 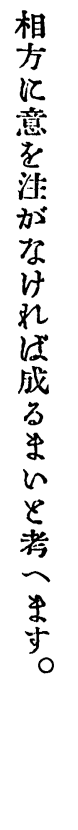 & 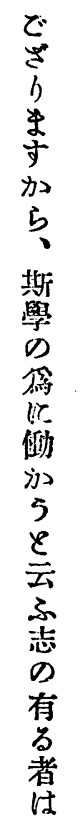 & 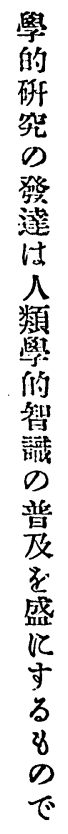 \\
\hline 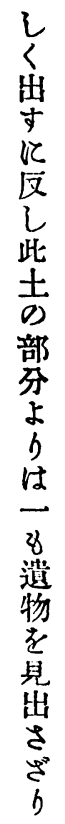 & 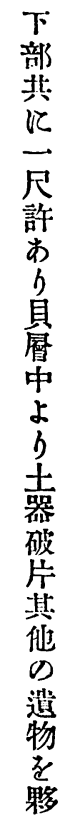 & 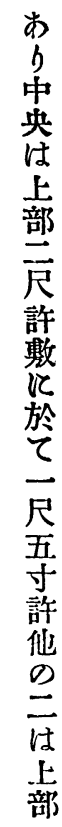 & 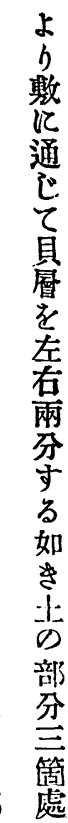 & 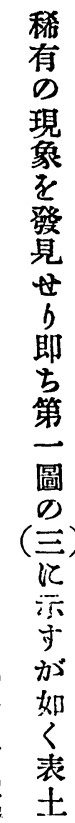 & 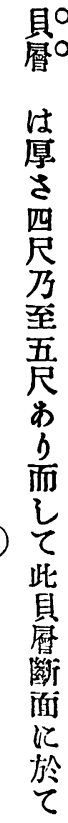 & it & 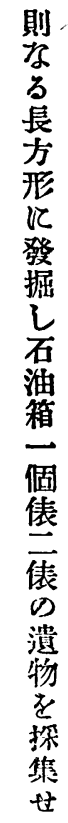 & 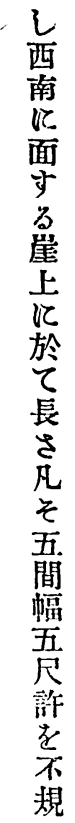 & 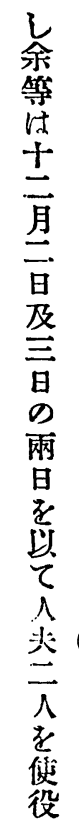 & 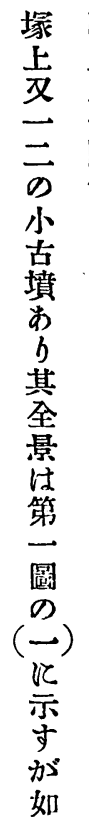 & 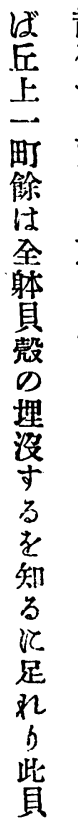 & 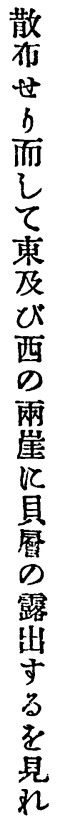 & 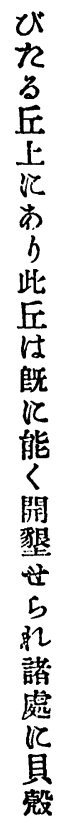 & 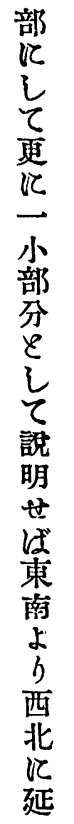 & 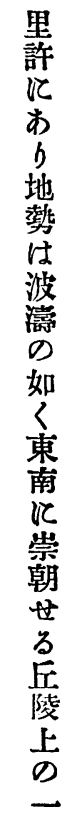 & 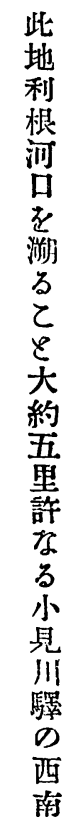 & $\begin{array}{l}\text { 下 } \\
\text { 總 } \\
\text { 香 } \\
\text { 郡 } \\
\text { 香 } \\
\text { 貲 } \\
\text { 塚 }\end{array}$ \\
\hline
\end{tabular}




\section{月十年九十二治 明}

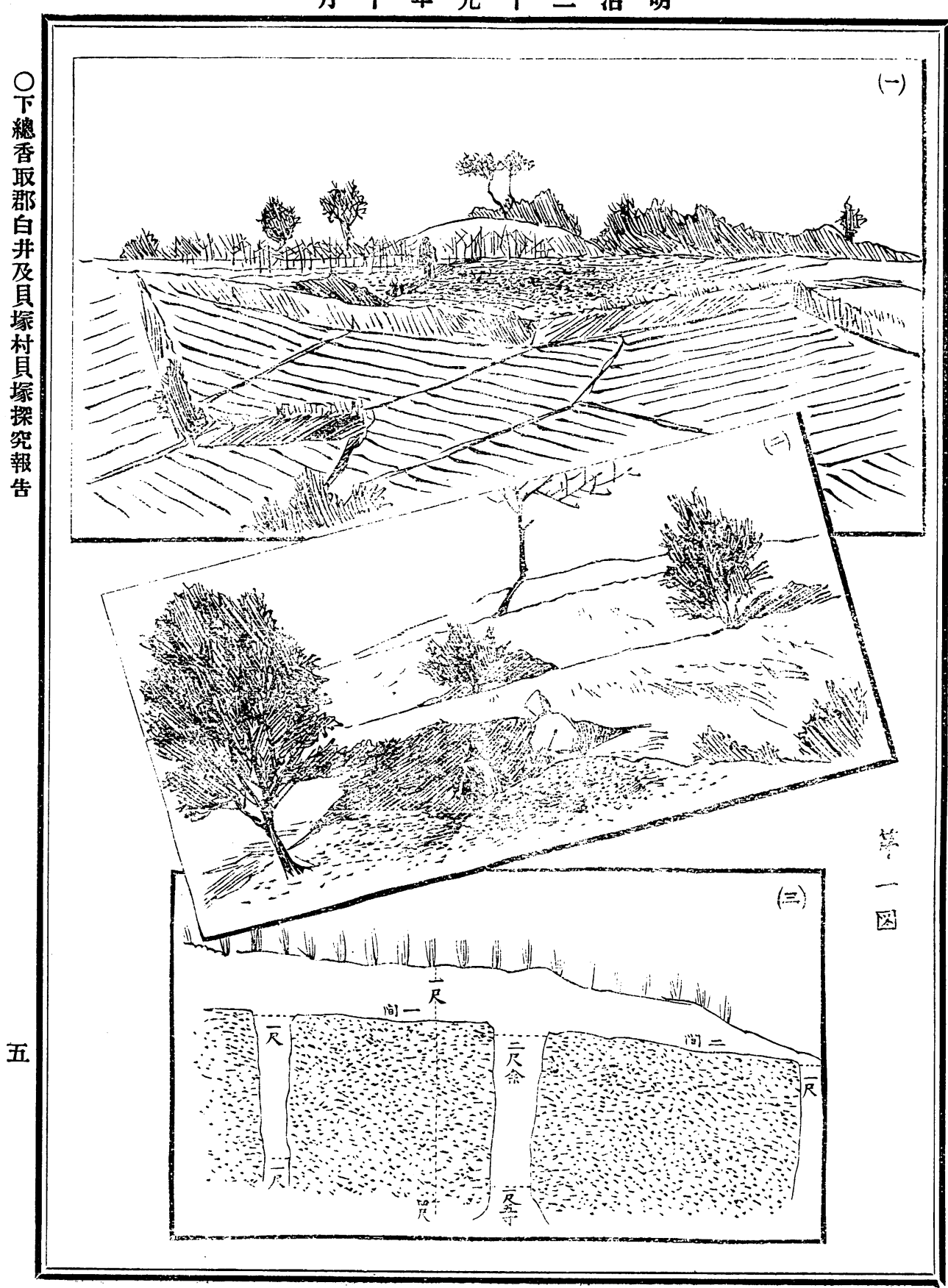




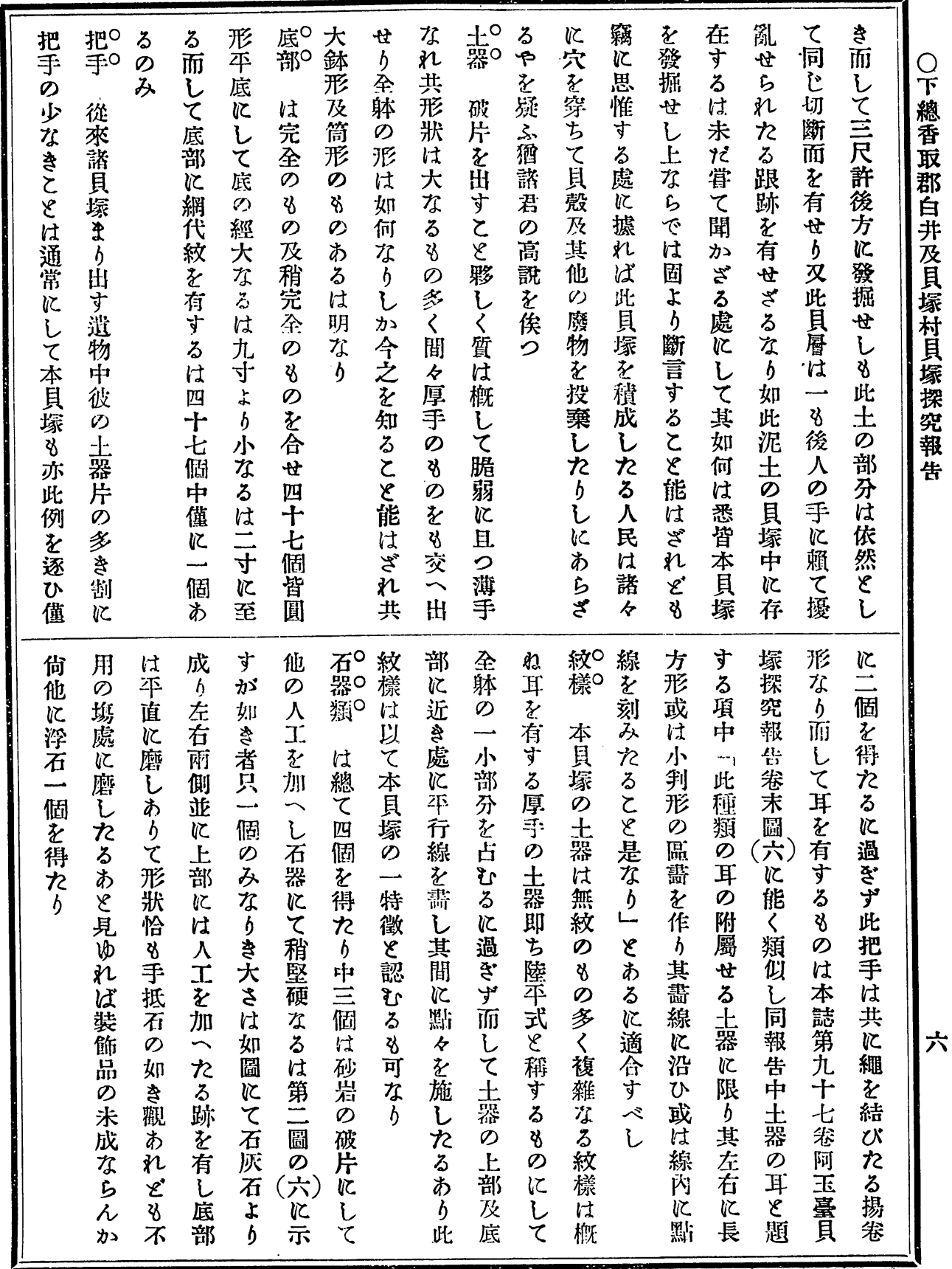


月十年九十二治明

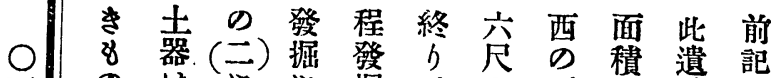

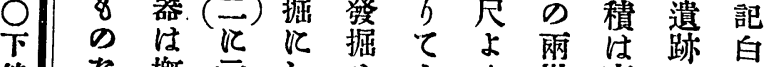
總な概示しせ十り岸東を刑 香し ね せ

取其溥し石本月文切三る 埰

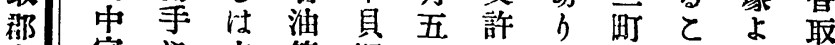

白完に本箱塚旦の 去許步方郡

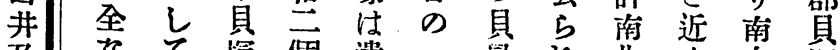

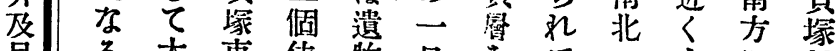

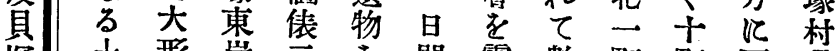

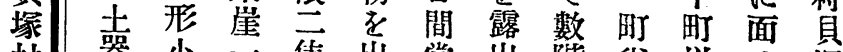

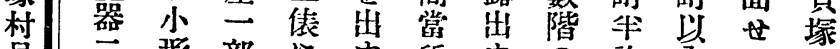

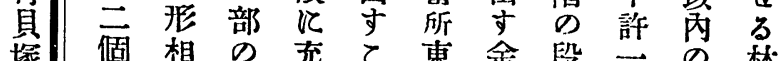

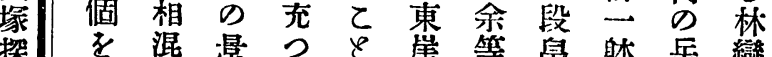

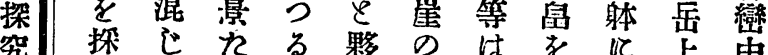

報 集 $\vec{b}$ 程乙貝白尔具学に

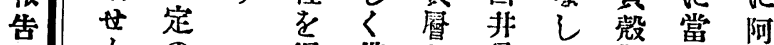
b得㒖を具其教所王 則式河凡塚切很の台 占第具貝 第認第 日五發面 万塚䝅 二四間六掘に東 圖 圆の坪を五庈り b
乙す王乙本骨。 る箈て 具 角。 あ及 無 嚗 頻 万片紋 所 這陸乲出 猪 は等る の 鹿 當 式を責 の 時江瑟物 骨 諸 類 比中等 部似前土他 落し號器貝 交九簡を塚 通る 單取 の分子 万大 有合る て 差 棣の紋 熟 虏 を厚稳 覽き 考をを市市 系者有 れ 如 るすすばし 材少る 薄 料し士手 次器大 る 存中形 心在阿治

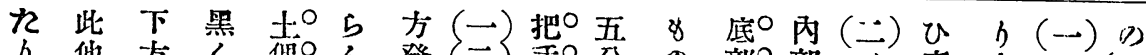

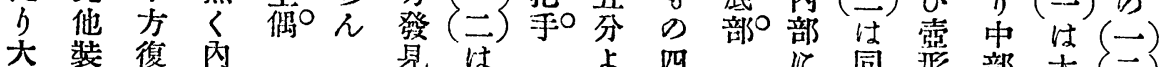

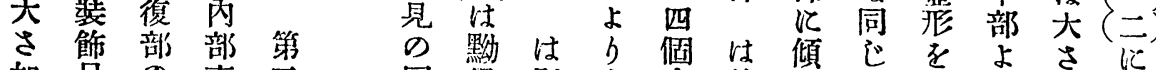

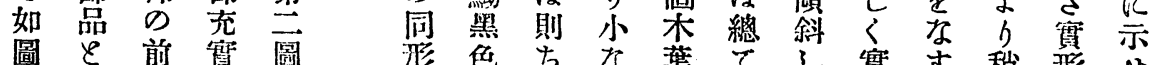

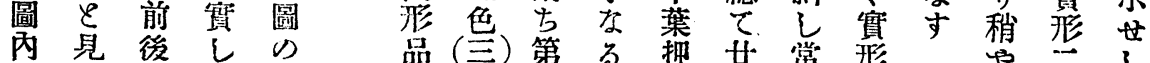

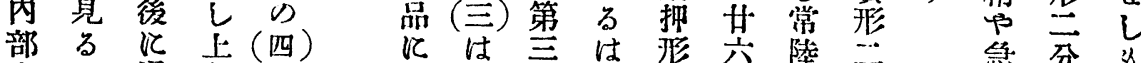
充心通部に加赤圖一娄個椎分急分的

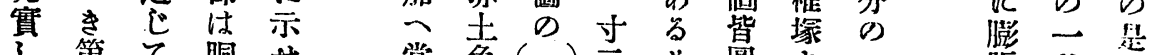
第七 胴世當 色 $(\vec{*})$ 云 8 圓

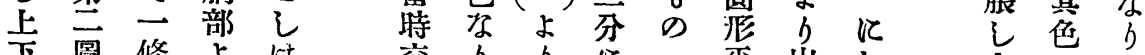
吕 (圆) 條

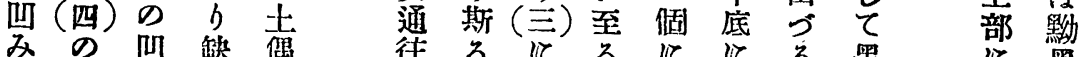

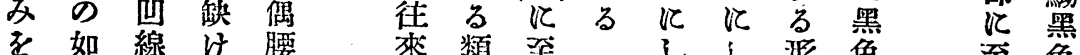

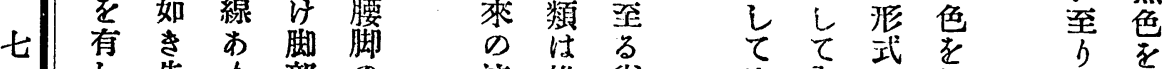

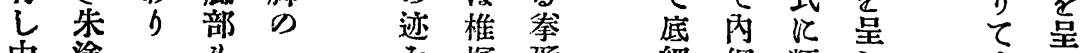

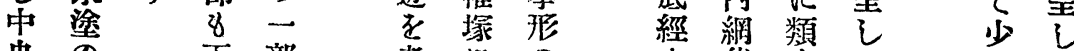

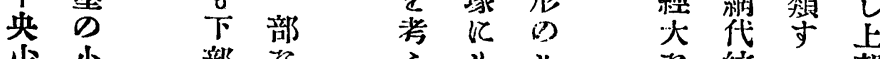

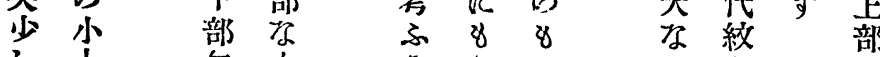

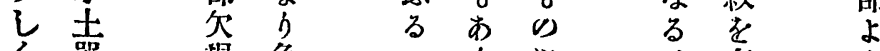

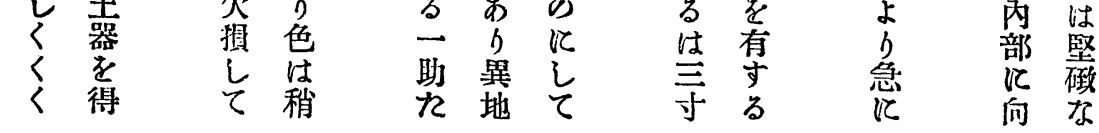


號七拾式百第誌雜會學類人京東

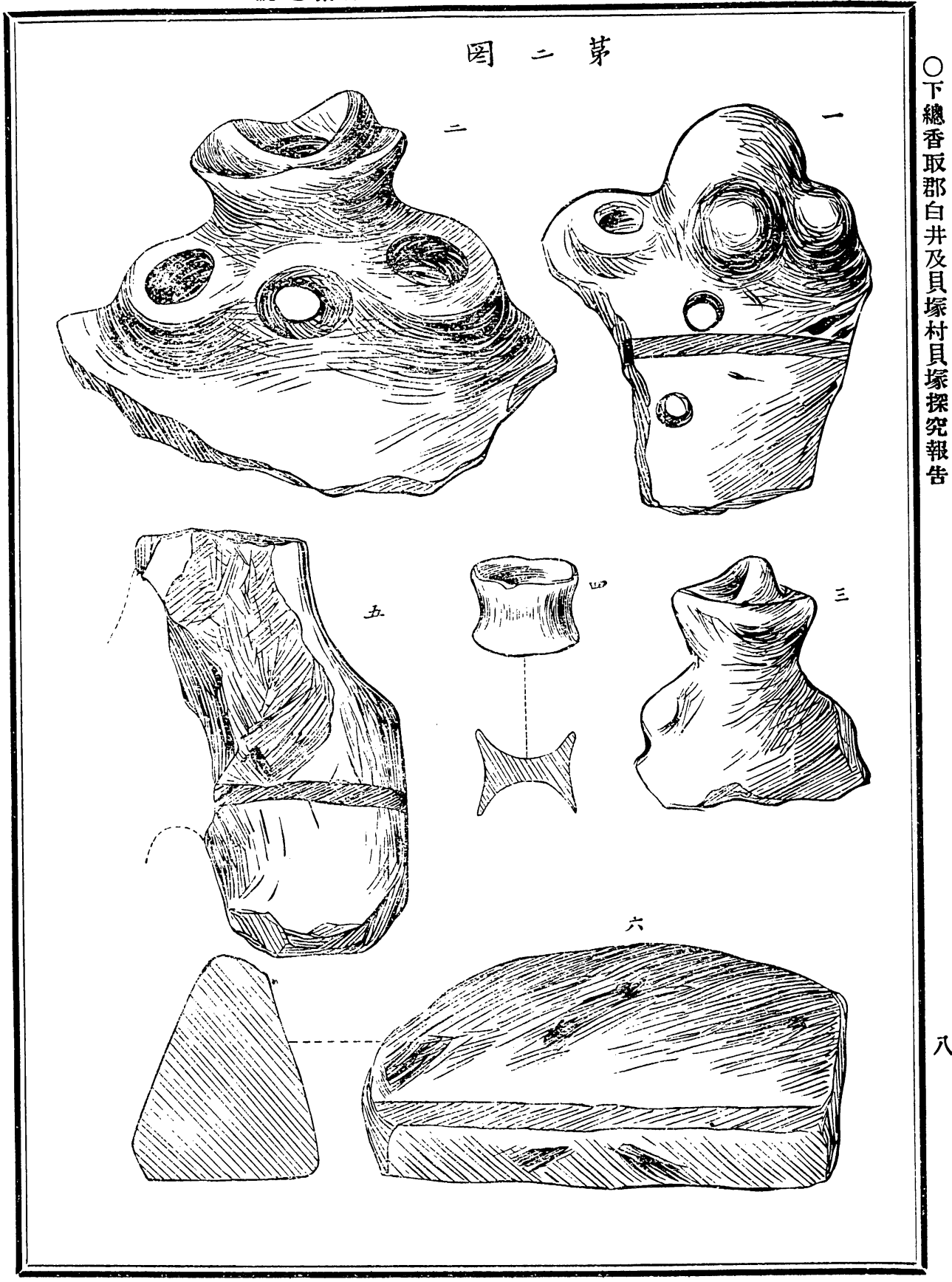




\section{月十年九十二治明}

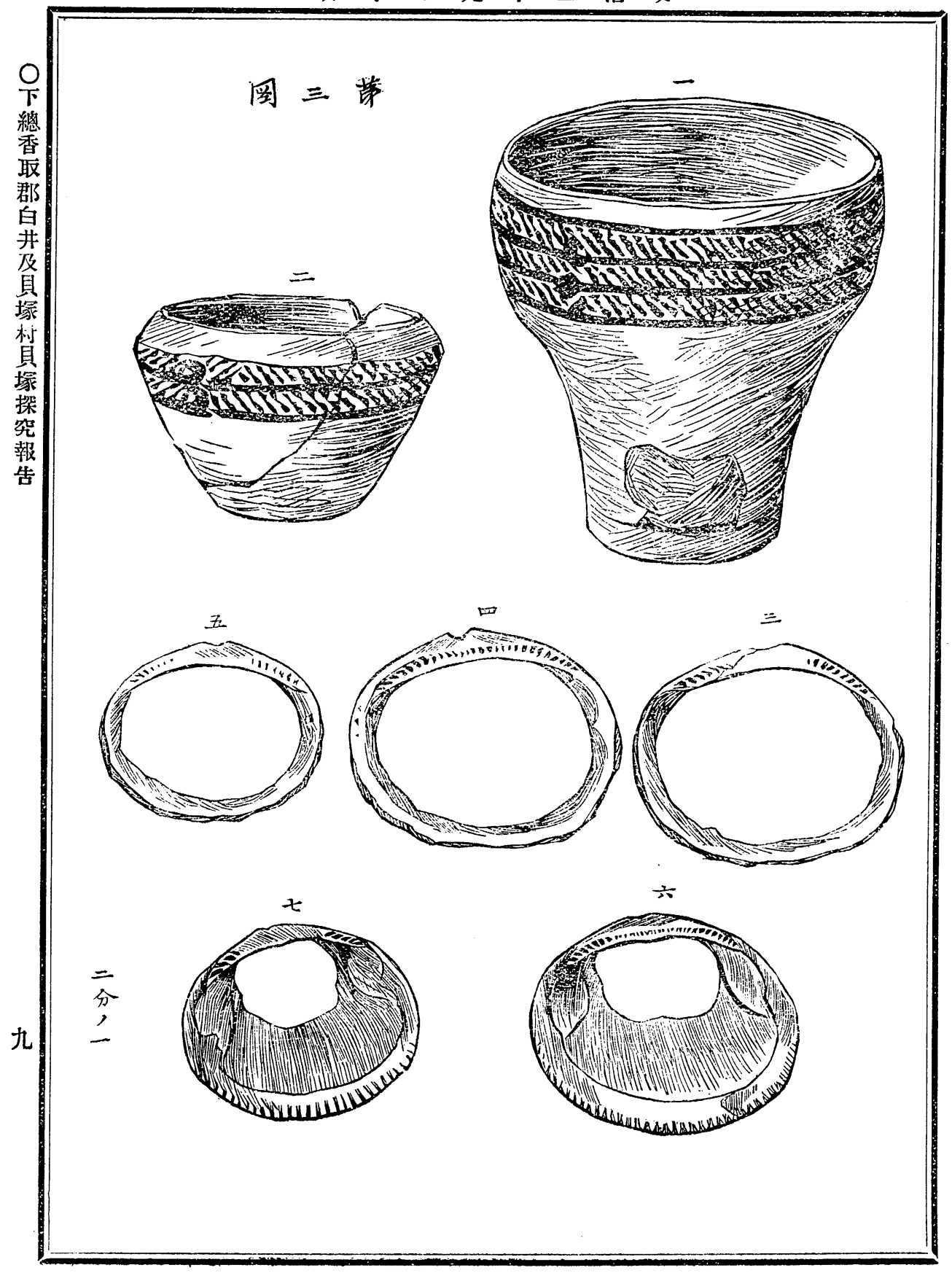




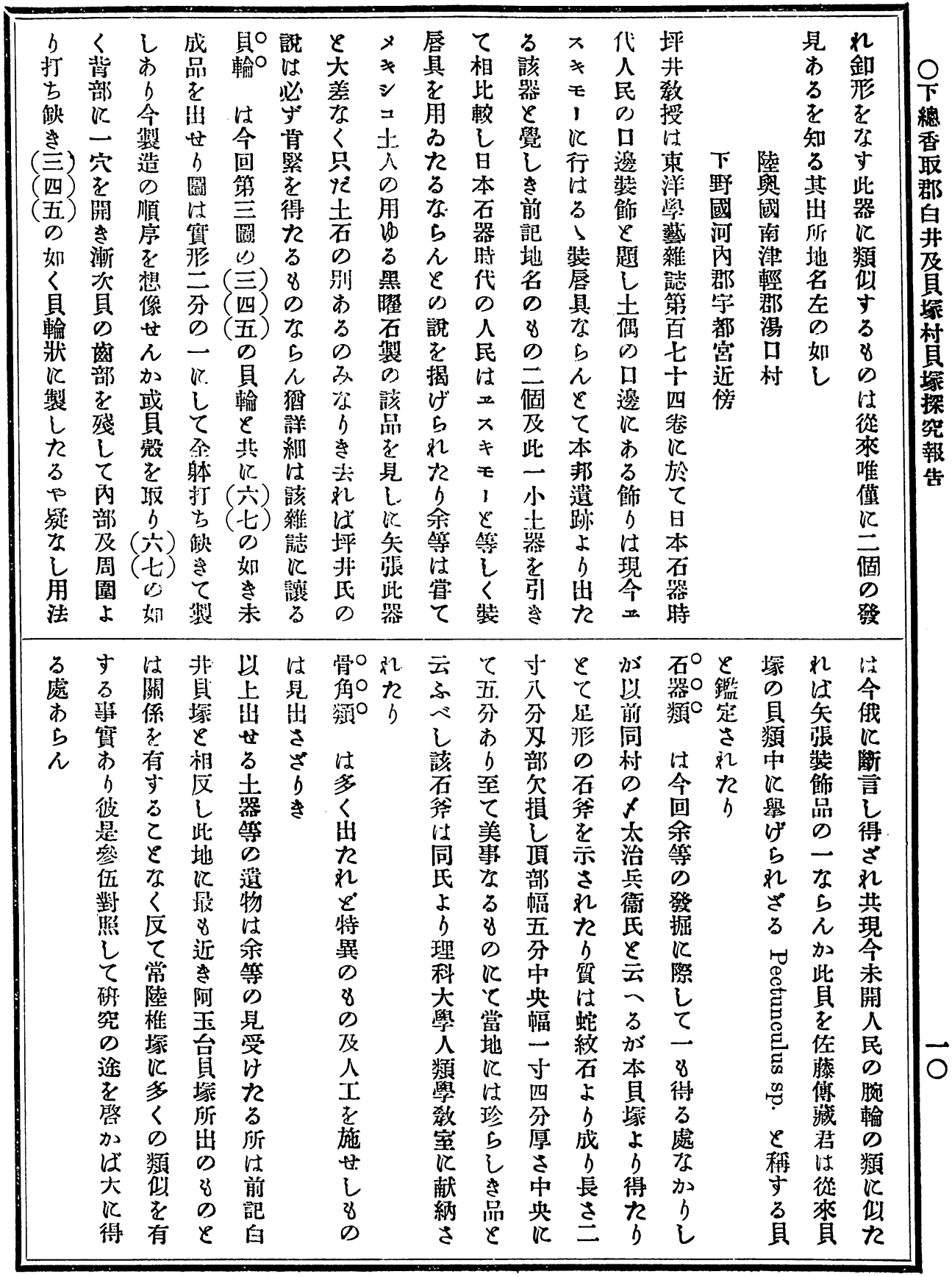




\section{月十年九十二治明}

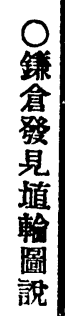

そく海八れ 新

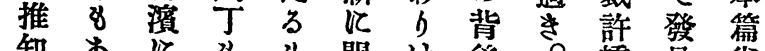

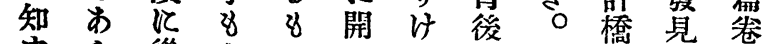

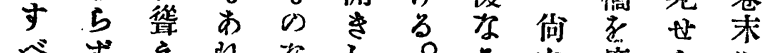

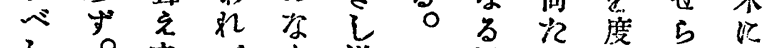

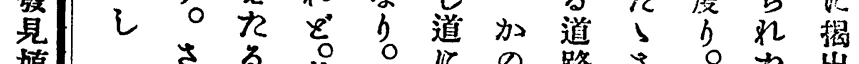

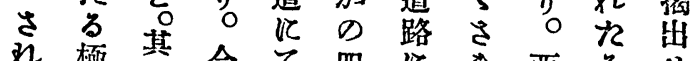

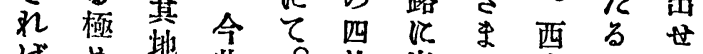
岕め地此 0 过出に南古方 古て埋邊此导方西海の 埔

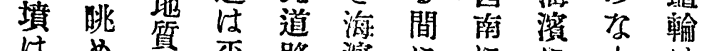

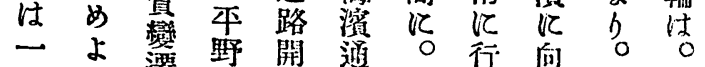

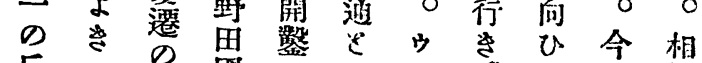

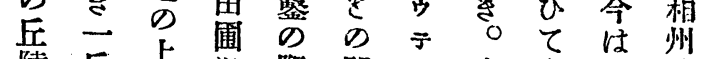
陵 $匚$ 上 上

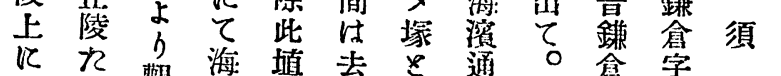

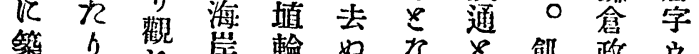

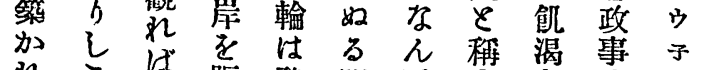

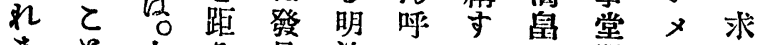
あと卡る見治心るるの問潒 万疑世出世云る 海四泩の臨

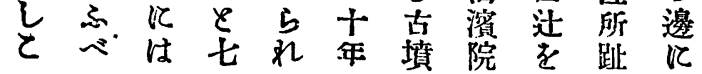

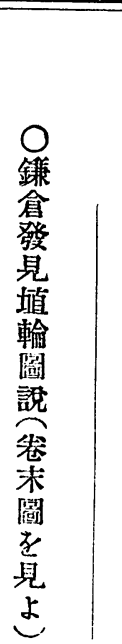

其比 影 際 上 志记恋 助 义 謝少的 すを 此 與 報 几 告 5 考 れ 終 元る る 同 留 村 学 の 具 醫 脿 们过 村 人 具 具塚 三 䓎 發 比掘 vi 向东 乙

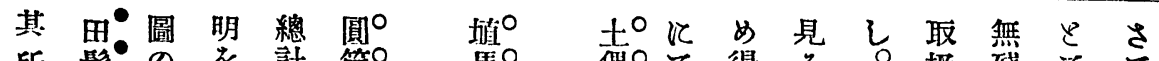

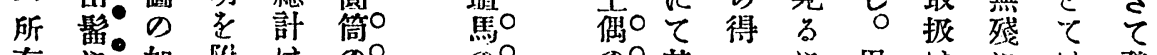

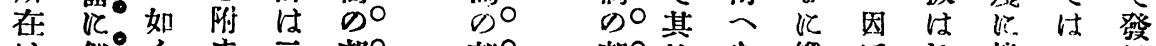

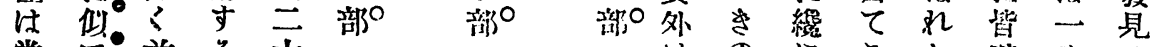

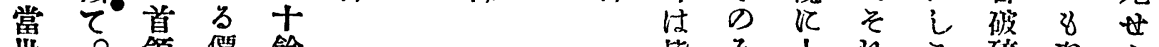

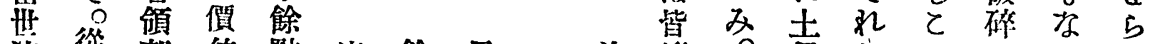

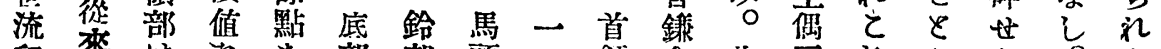

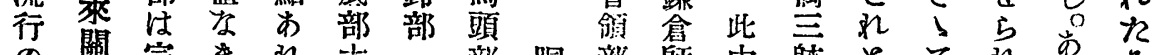

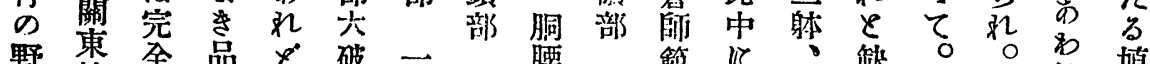

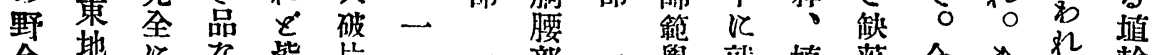
合方地尔皆片, 一部一學就埴落今各犯輪

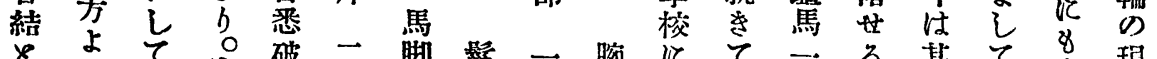
飞

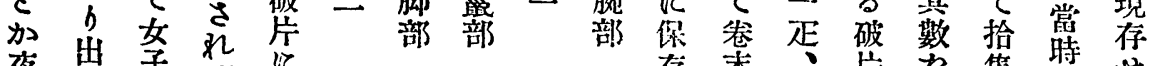

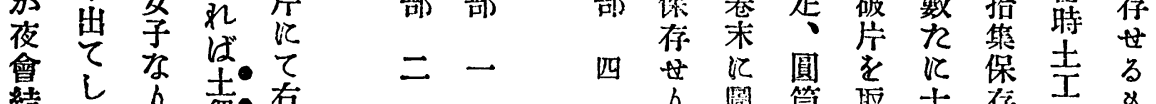

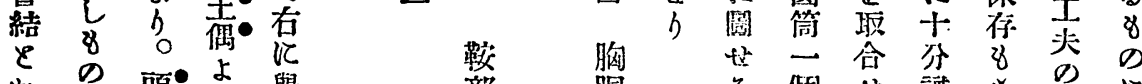

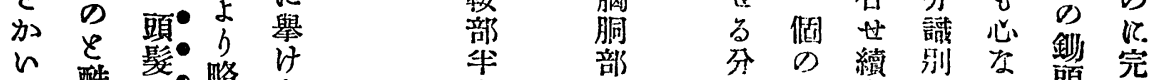

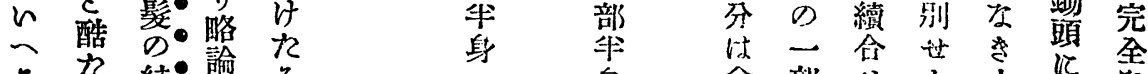

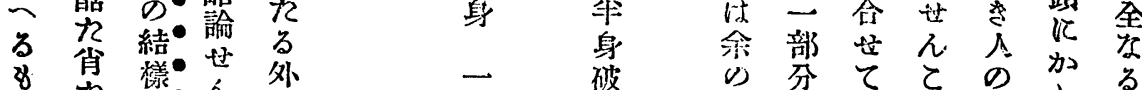

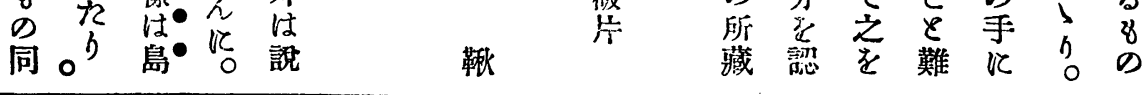

